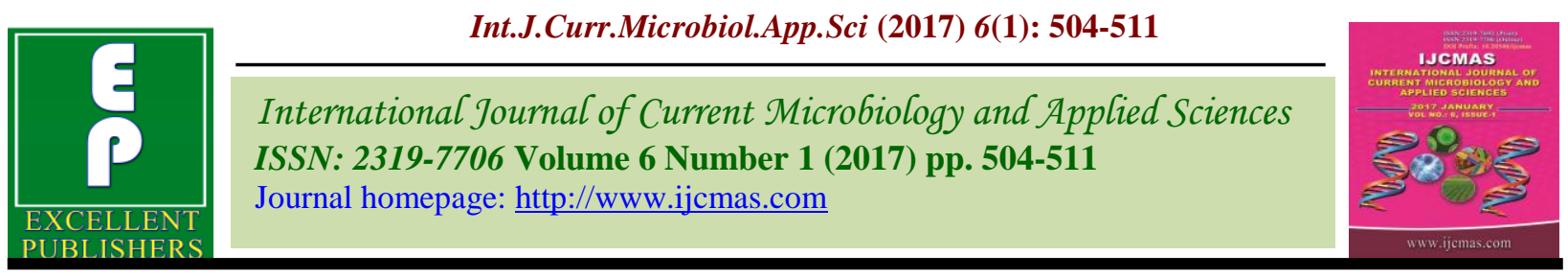

Original Research Article

http://dx.doi.org/10.20546/ijcmas.2017.601.060

\title{
Isolation and Purification of Antibacterial Peptide from Bacillus safensis, Endophytica Bacteria from Anthocephalus kadamba
}

\author{
Priya D. Kakade* and Sushma R. Chaphalkar \\ Vidya Pratishthan's School of Biotechnology, Vidyanagari, Baramati, \\ Pune-413133, Maharashtra, India \\ *Corresponding author
}

\section{A B S T R A C T}

\begin{tabular}{|l|}
\hline K e y w o r d s \\
Endophytic bacteria, \\
antimicrobial peptide, \\
16 s rDNA \\
technology, Fast \\
Protein Liquid \\
Chromatography. \\
\hline Article Info \\
\hline $\begin{array}{l}\text { Accepted: } \\
\text { 23 December } 2016 \\
\text { Available Online: } \\
\text { 10 January } 2017\end{array}$ \\
\hline
\end{tabular}

The endophytic bacteria is refers to as interior colonization of plants. Endophytic bacteria or fungi colonize the host tissue internally, sometimes in high numbers, without damaging the host or eliciting symptoms of plant disease according to a widely used. In recent work for the isolation and characterization of endophytic bacteria the medicinal trees was selected from Nakshatra Udyan. There were number of reports of the medicinal components present in the plants being the metabolic products of endophytic bacteria. Hence, the nakshatra trees can be the potent source of these metabolites which is having beneficial role for all living system. Accordance to this it was hypothesized that the endophytic bacteria isolated from the nakshatra tress were source for the antimicrobial peptides, biocontrol agent, plant growth promoting hormone. For the isolation of endophytic bacteria the medicinal trees Anthocephalus kadamba was selected. The isolation of endophytic bacteria was carried out from leaf of plant. Identification of endophytic bacteria was done by microbiological and biochemical aspects observing microscopic characteristics and biochemical characteristics by using Bergey's manual of Determinative and Systematic. The Bacillus sp. was prominent in this isolation. The isolates were identified at molecular level by using the $16 \mathrm{~s} r$ DNA technology. The phylogenetic analysis was done by using bioinformatics tools. The isolates were screened for antimicrobial peptide and characterization of these metabolites was done by using Fast Protein Liquid Chromatography.

\section{Introduction}

Endophytes are the bacteria which reside inside the plant tissue without causing the harm to plant tissue, which is having ubiquitous symbiotic association with host plant. Their presence has been seen in different plant parts like flower, leaf, root and stem. They are known to secrete different types of secondary metabolites like antimicrobial peptides, growth promoting hormones and bioactive compounds which are used as biocontrol agent, in pharmacology used as antimicrobial drugs preparation, in food industry and agriculture (Dhanya et al., Susheel kumar et al.). These endophytic bacteria play an important role for improvement in growth and health of plant and it has several mechanisms for it (Taghavi et al., 2009). Endophytes may directly produce chemical defense in plants through the production of secondary compounds which inhibit insects and pathogenic organisms. The in vitro secretion of 
substances by endophytes that limit the growth of other microbial species, includes pathogens (Vania Specian et al., 2012). The many of endophytes re poorly investigated group of microorganisms that produces secondary metabolites which is used in modern medicine and about $40 \%$ of the prescription of drugs are based on them (Shukla et al., 2014). The endophytic bacteria produces Indole Acetic acid (IAA) (Pedraza et al., 2004), cytokinin (Ergun et al., 2002) and Gibberellic acid (GA) (Kharwar et al., 2008) which are required for the plant growth. In the 70's, endophytes were initially considered neutral, neither causing benefits nor showing detrimental influence on plants, but from the results of more recent studies it has been possible to show that in many cases, they have an important role in host protection against pathogens. Several studies have now shown that the interaction between plants and some endophytic bacteria is associated with beneficial effects such as plant growth promotion and biocontrol potential against plant pathogens (Lalande et al.,, 1989; Bashan et al., 1990; Chen et al., 1995; Hallmann et al., 1998).

\section{Materials and Methods}

\section{Selection of medicinal plants and Explants collection}

For the isolation of bacteria the explants were collected from Anthocephalus kadamba plant which was part of Nakshtra Udyan which located at Vidya Pratishthan's school of biotechnology. The cultivation of these plants was strictly maintained in organic package and the age of plants was fourteen years.

\section{Pretreatment and surface sterilization of explants}

The explants used for the isolation were leaves, stem and root of the plants. The collected explants was brought to the laboratory and washed under running tap water. After this these were thoroughly washed with distilled water. Surface sterilization protocol was standardized which contained surface sterilizing agents like $1 \%$ phenolic compounds containing solution for 5 min followed by $0.1 \%$ sodium hypochlorite treatment for $5 \mathrm{~min}$. Afterwards the explants was washed with sterile distilled water.

\section{Isolation of endophytic bacteria}

The samples were aseptically ground in a motor and pestle in potassium dihydrogen phosphate buffer ( $\mathrm{pH}$ 6.8) and inoculated into sterile nutrient broth medium with negative and positive control i.e. sterilized medium without inoculation of explants and uncrushed surface sterilized explants. The broth was incubated for $24 \mathrm{hrs}$ at $30^{\circ} \mathrm{C}$ on rotary shaker incubator at $120 \mathrm{rpm}$. The grown culture was plated onto sterile nutrient agar plates. The plates were incubated at $37 \mathrm{C}$ for $24 \mathrm{hrs}$. The isolated bacteria were plated onto selective medium after their morphological, biochemical and molecular identification and preserve it by lyophilization.

\section{Biochemical characterization of isolates}

The standard tests for the characterization were done according to the Beregey's Mannual of Determinative Bacteriology. The isolates were characterized for colony characterization which includes size, shape, color, consistency, opacity, Gram's nature, Capsule staining and presence of endospores. The biochemical characterization was done for IMViC test, starch hydrolysis, gelatin liquefaction, and different sources of carbon utilization, Oxidase and catalase tests by standard methods.

\section{Molecular Characterization of isolates}

The isolated strains were identified by using 16 s r DNA techniques. The genomic DNA of 
endophytic bacteria was isolated by using CTAB method. The amplification of template DNA was done by using universal primes, R1 forward (5'AGTTTGATCCTGGCTCAG 3') and $\mathrm{R} 2$ reverse (5' GGACTACCAGGGTAT CTAAT3'). The 50 ul PCR reaction contains $\mathrm{Mgcl}_{2}(0.45 \mathrm{mM})$, dNTPs $(0.2 \mathrm{mM})$, forward primer $(10 \mathrm{pmol})$, reverse primer $(10 \mathrm{pmol})$, Taq polymerase $(0.5 \mathrm{U})$ having $10 \mathrm{X}$ assay buffer(1X), genomic DNA(1 ug/ul) and sterile MilliQ water is used.

Amplification of DNA was done in automated thermocycle machine provided by applied biosystem and product was checked on $1 \%$ agarose gel. The gel was eluted by using SIGMA gel elution kit.

The sequencing reaction was carried out in 3130 genetic analyzer at VSBT. The BLAST of the sequences was done for sequences of bacteria to NCBI GeneBank.

\section{Phylogenetic tree analysis}

The phylogenetic tree was constructing by using MEGA software. The neighbor-joining method was used to construct the phylogenetic tree. The bootstrap resampling test with 100 replications was also applied.

\section{Antimicrobial activity}

The endophytic isolates were screen for antimicrobial activity. The isolate VCC.22.LA( Ea7) was fermented in nutrient broth. After $24 \mathrm{hrs}$ incubation at $37^{\circ} \mathrm{C}$, centrifuge the culture broth at $10,000 \mathrm{rpm}$ for $10 \mathrm{~min}$. Take the cell free extract to check the antimicrobial activity.

The bactericidal activity checked by using well diffusion assay. The antimicrobial peptides were precipitated by using $80 \%$ ammonium sulphate. Further purification of peptide was done by using FPLC.

\section{Results and Discussion}

The endophytic bacteria isolated from Anthocephalus kadamba plant. It shows the dominance of Bacillus species includes $B$. megaterium, B. axarquiensis, $B$. safensis, B.pumilus, B. cereus and Ochromobacterium $s p$. which were biochemically characterized and compare by using Bergey's Mannula of Determinative and systematic Bacteriology (Table.1,2,3,4,5).

Table.1 Comparative table for Endophytic and B. megaterium

\begin{tabular}{|l|l|l|}
\hline Test & VCC.22.LD & B. megaterium \\
\hline $\begin{array}{l}\text { Starch } \\
\text { utilization }\end{array}$ & - & + \\
\hline V.P & + & - \\
\hline $\begin{array}{l}\text { Sugar: acid } \\
\text { formation }\end{array}$ & & \\
\hline Sucrose & - & + \\
\hline Lactose & - & + \\
\hline Arabinose & - & + \\
\hline Host plant & Kadamb(L) & \\
\hline
\end{tabular}


Table. 2 Comparative table for endophytic and B. axarquiensis

\begin{tabular}{|l|l|l|}
\hline Test & VCC.22.LC & B. axarquiensis \\
\hline Oxidase test & + & - \\
\hline Sugar: acid production & & \\
\hline Glucose & - & + \\
\hline Arabinose & - & + \\
\hline Host plant & Kadamb(L) & \\
\hline
\end{tabular}

Table.3 Comparative table for endophytic and non endophytic B. safensis

\begin{tabular}{|l|l|l|}
\hline Test & VCC.22.LA & B.safensis \\
\hline Citrate utilization & - & + \\
\hline Sugar: acid production & & \\
\hline Arabinose & - & + \\
\hline Mannitol & - & + \\
\hline Host plant & Kadamb (L) & \\
\hline
\end{tabular}

Table.4 Comparative table for endophytic and B.pumilus

\begin{tabular}{|l|c|c|}
\hline Test & VCC.22.LG & B.pumilus \\
\hline Citrate utilization & + & - \\
\hline Starch hydrolysis & + & - \\
\hline Oxidase test & - & + \\
\hline Sugar: acid production & & \\
\hline Fructose & - & + \\
\hline Mannitol & - & + \\
\hline Host plant & Kadamb(L) & \\
\hline
\end{tabular}

Fig.1 Inoculated tubes showing the growth of endophytic bacteria: Test tube1. Negative control, Test tube2. Positive control, Test tube 3 and 4: Crushed explants of Anthocephalus kadamba.

Isolation of endophytic bacteria

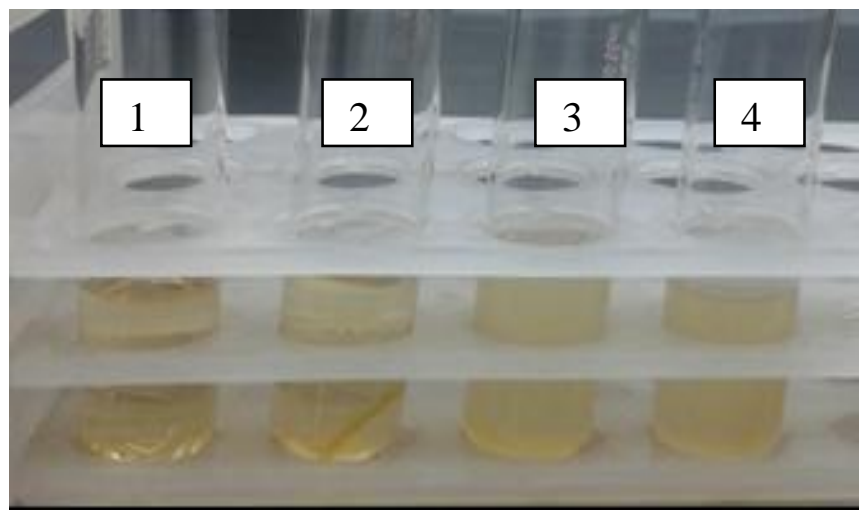


Table.5 Comparative table for endophytic and B. cereus

\begin{tabular}{|l|l|l|l|}
\hline Test & VCC. 22.LF & VCC. 15.LG & B. cereus \\
\hline Citrate utilization & + & - & + \\
\hline Starch hydrolysis & + & - & + \\
\hline Gelatin liquefaction & - & + & + \\
\hline V.P. test & - & + & + \\
\hline Indole test & - & - & - \\
\hline Oxidase test acid & + & - & + \\
\hline $\begin{array}{l}\text { Sugar: } \\
\text { production }\end{array}$ & & & \\
\hline Glucose & + & & \\
\hline Fructose & + & + & + \\
\hline Sucrose & - & + & + \\
\hline Lactose & - & + & + \\
\hline Arabinose & + & + & - \\
\hline Xylose & - & - & - \\
\hline Mannitol & - & + & - \\
\hline Rhamnose & + & + & - \\
\hline Host plant & Kadamb(L) & - & - \\
\hline
\end{tabular}

Table.6 Comparative analysis of endophyte and Ochromobacterium sp.

\begin{tabular}{|l|c|c|}
\hline Test & $\begin{array}{l}\text { VCC. } \\
22 . \text { LB }\end{array}$ & $\begin{array}{l}\text { Ochromobacterium } \\
\text { sp. }\end{array}$ \\
\hline Citrate utilization & - & - \\
\hline Starch hydrolysis & - & - \\
\hline $\begin{array}{l}\text { Gelatin } \\
\text { liquefaction }\end{array}$ & - & - \\
\hline V.P. test & + & - \\
\hline Indole test & - & + \\
\hline Oxidase test & - & \\
\hline $\begin{array}{l}\text { Sugar: } \\
\text { acid production }\end{array}$ & & + \\
\hline Glucose & + & + \\
\hline Fructose & - & - \\
\hline Sucrose & - & - \\
\hline Lactose & + & + \\
\hline Arabinose & + & + \\
\hline Xylose & + & - \\
\hline Mannitol & + & + \\
\hline Rhamnose & - & \\
\hline Host plant & Kadamb(L) & \\
\hline
\end{tabular}


Fig.2 Biochemical Characterization of isolated Bacillus safensis

\section{Biochemical Characterization of endophytic bacteria:}

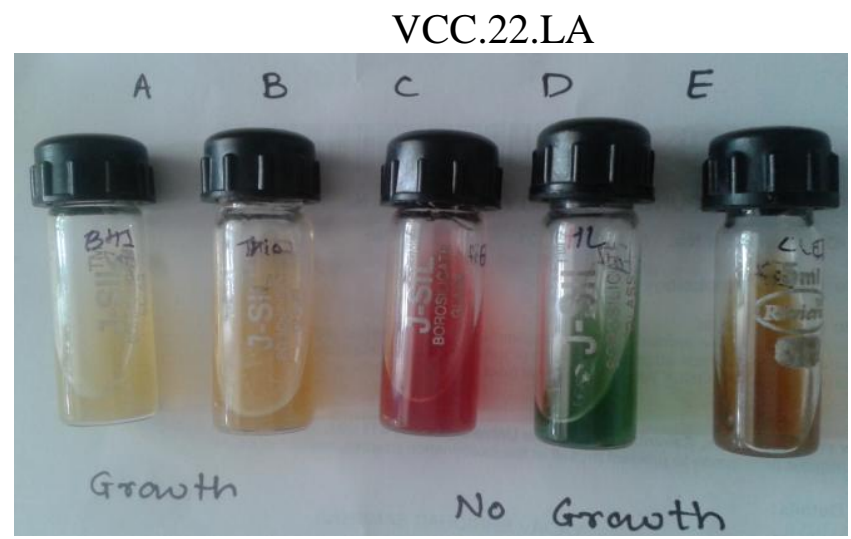

Fig.3 Neighbour Joining method for phylogenetic analysis using MEGA 3.1 software

\section{Phylogenetic Analysis of isolates}

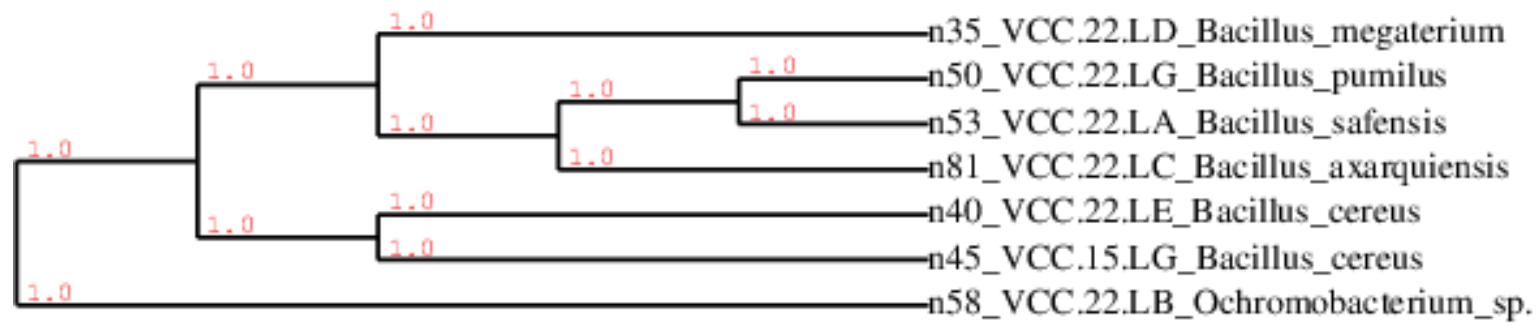

Fig.4 Activity of crude cell-free supernant of VCC.22.LA (Ea 7) against Pseudomonas sp.

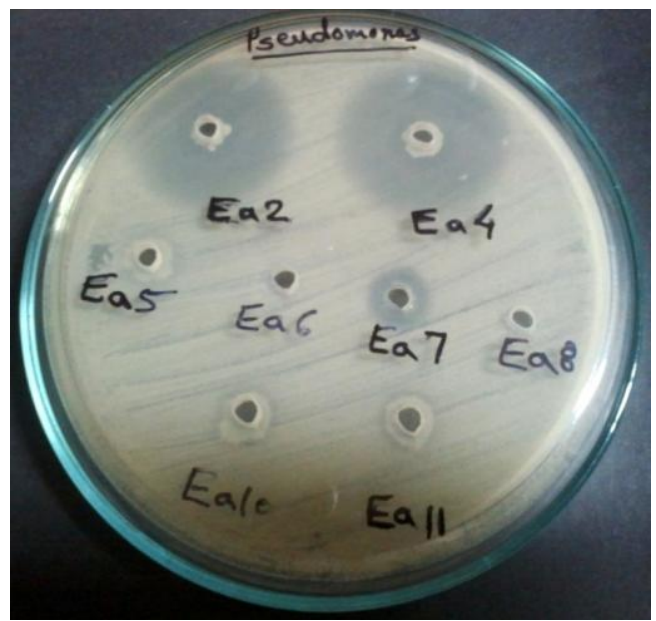


Fig.5 Activity of Purified Protein

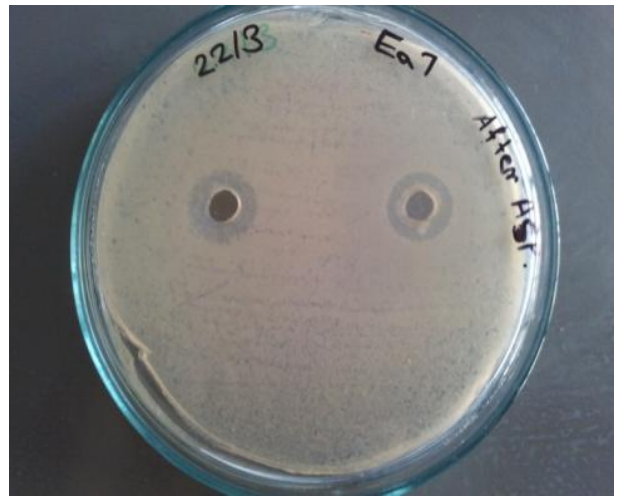

Fig.6 Fast Protein Liquid Chromatography plot shows P1 and P2 two separate peak.

\section{Purification of antimicrobial Peptides produced by B.safensis}

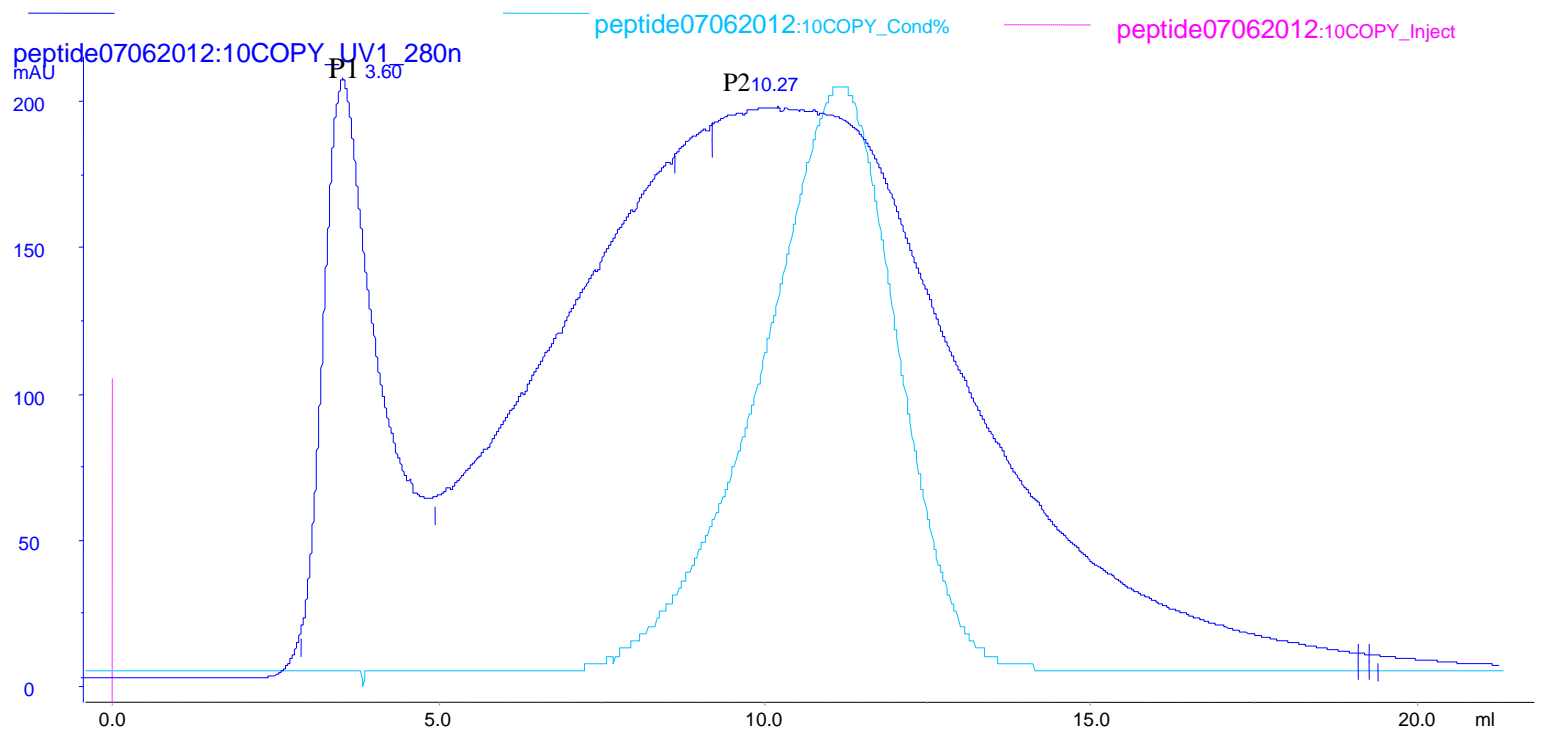

The 16 s rDNA techniques have been used for identification of isolates and Neighbour Joining method was used for phylogenetic analysis by using MEGA 3.1 software (Fig.1,2,3). Among isolated bacteria VCC.22.LA (Bacillus safensis) was showing the antimicrobial activity against Pseudomonas sp. of crude sample in which cell suspension was inoculated (Fig.4). After ammonium precipitation the peptide was precipitated out and checked against Pseudomonas sp. shows $13 \mathrm{~mm}$ zone of inhibition. Further analysis was done by using Fast Protein Liquid Chromatography. This shows two different peaks of P1 and P2 (Fig.6).

\section{Acknowledgment}

The authors are very thankful to Department of Biotechnology, New Delhi for financial support and also to VSBT for providing laboratory for experiments.

\section{References}

Bashan, Y., Holguin, G. 1998. Proposal for the division of plant growth-promoting rhizobacteria into two classifications: 
biocontrol-PGPB (plant growth promoting bacteria) and PGPB. Soil Biol. Biochem., 30: 1225e1228.

Chandra Datta Sumi, et al. 2014. Antimicrobial peptides of the genus Bacillus: a new era for antibiotics. Canadian J. Microbiol., 61(2): 93-103.

Dhanya, N., Nair and S. Padmavathy. 2014. Impact of Endophytic Microorganisms on Plants, Environment and Humans. The Scientific World J.

Ergun, N., S.F. Topcuoglu and A. Yildiz. 2002. Auxin (Indole-3-acetic acid), gibberellic acid $\left(\mathrm{GA}_{3}\right)$, abscisic acid (ABA) and cytokinin (Zeatin) Production by some species of mosses and lichens. Turk. J. Bot., 26: 13-19.

Hallmann, J., Quadt-Hallmann, A., Mahaffee, W.F., and Kloepper, J.W. 1997. Bacterial endophytes in agricultural crops. Can. J. Microbiol., 43: 895-914.

Kharwar, R.N., V.C. Verma, G. Strobel and D. Ezra. 2008. The endophytic fungal complex of Catharanthus roseus (L.) G. Don. Curr. Sci., 95: 228-233.

Lalande, R., Bissonette, N., Coutlée, D. and Antoun, H. 1989. Identification of rhizobacteria from maize and determination of their plant-growth promoting potential. Plant Soil, 115: 711.

Muna Ali Abdalla et al. 2014. Endophytes as Producers of Peptides: An Overview About the Recently Discovered Peptides from Endophytic Microbes. Nat. Prod. Bioprospect, 4(5): 257-270.

Pedraza, R.O., Ramirez-Mata, A., Xiqui, M.1. and Baça Be. 2004. Aromatic amino acid aminotransferase activity and indole-3-acetic acid production by associative nitrogen-fixing bacteria. FEMS Microbiol. Lett., 233: 15-21.

Shukla, S.T., P.V. Habbu, V.H. Kulkarni, K.S. Jagadish, Aprajita, R., Pandey, V.N. Sutariya. 2014. Endophytic microbes: A novel source for biologically/pharmacologically active secondary metabolites. Asian $J$. Pharmacol. Toxicol., 02(03): 01-16

Safiyh Taghavi, et al. 2009. Genome Survey and Characterization of Endophytic Bacteria Exhibiting a Beneficial Effect on Growth and Development of Poplar Trees. Appl. Environ. Microbiol., 75(3): 748-757.

Sruthy, K.S. et al. 2015. Isolation, Purification and Characterization of Antimicrobial Peptides from Indian Ruff, Psenopsis cyanea (Alcock, 1890). Int. J. Res. Biol. Sci., 5(1): 1-6

Sunayana Sharma, et al. 2014. Cationic Bioactive Peptide from the Seeds of Benincasa hispida. Hindawi Publishing Corporation: Volume 2014: 1-12.

Tejesvi, M.V., et al. 2016. MB1533 is a Defensin-Like Antimicrobial Peptide from the Intracellular Meristem Endophyte of Scots Pine Methylobacterium extorquens DSM13060. J. Microb. Biochem. Technol., 8: 1.

Vânia Specian, et al. 2012. Chemical characterization of bioactive compounds from the endophytic fungus Diaporthe helianthi isolated from Luehea divaricata. Brazilian $J$. Microbiol., 1174-1182.

\section{How to cite this article:}

Priya D. Kakade and Sushma R. Chaphalkar. 2017. Isolation and Purification of Antibacterial Peptide from Bacillus safensis, Endophytica Bacteria from Anthocephalus kadamba. Int.J.Curr.Microbiol.App.Sci. 6(1): 504-511. doi: http://dx.doi.org/10.20546/ijcmas.2017.601.060 